\title{
Nicotine interferes with purinergic signaling in smooth muscle cells isolated from urinary bladders of patients with lower urinary tract symptoms
}

\author{
Agnes Jenes $^{1 \#}$, Gyula P. Szigeti1 ${ }^{\#}$, Ferenc Ruzsnavszky $^{1}$, Attila Varga $^{2}$, Laszlo Lorincz $^{2}$ \\ and Laszlo Csernoch ${ }^{1}$ \\ ${ }^{1}$ Department of Physiology, Medical and Health Science Center, University of Debrecen, Debrecen, Hungary \\ ${ }^{2}$ Department of Urology, Medical and Health Science Center, University of Debrecen, Debrecen, Hungary
}

\begin{abstract}
In patients with outlet obstruction, the contraction of the base is reduced compared to that of healthy individuals, while the contraction of the dome is not affected. Here, we investigated the cellular mechanisms that might be responsible for cholinergic effects blocking non-adrenergic non-cholinergic contractions in the base of the urinary bladder.

Smooth muscle cells either from the base or from the dome of human urinary bladders were cultured to determine the contribution of cholinergic and purinergic mechanisms to their $\mathrm{Ca}^{2+}$ homeostasis.

While ATP evoked $\mathrm{Ca}^{2+}$ transients in all the cells, nicotine and carbachol induced $\mathrm{Ca}^{2+}$ transients only in $56 \%$ and $44 \%$ of the cells, respectively. When ATP was administered together with nicotine or carbachol, the amplitudes of the $\mathrm{Ca}^{2+}$ transients recorded from cells prepared from the base of bladders were significantly smaller ( $42 \pm 6 \%$ with nicotine and $56 \pm 9 \%$ with carbachol) than those evoked by ATP alone. This inhibition was much less apparent in the dome of bladders.

The inhibition between the cholinergic and purinergic signaling pathways reported in this work may decrease the strength of the contraction of the base of the urinary bladder in patients with outlet obstruction during voiding.
\end{abstract}

Key words: Human urinary bladder - Smooth muscle - Nicotinic acetylcholine receptors - P2X purinergic receptors - Interaction

\section{Introduction}

During aging, the human urinary bladder undergoes significant plasticity that contributes to the development of detrusor overactivity, impaired contractility, or the combination of both (Malone-Lee and Wahedna 1993; Yoshida et al. 2001). The originally flawless storage and emptying function of the bladder becomes altered, partly as a result of changes in bladder smooth muscle and connective tissue function, in addition to changes in afferent and efferent innervations

Correspondence to: Laszlo Csernoch, Department of Physiology, Medical and Health Science Center, University of Debrecen, Nagyerdei krt. 98, PO Box 22, Debrecen, Hungary

E-mail: csl@edu.unideb.hu

\# These authors contributed equally to this work.
(Resnick and Yalla 1987). While 4-D ultrasound images of healthy human bladders show uniform contraction during voiding, the shortenings of the upper and lower parts of urinary bladders with outlet obstruction are different (Hirahara et al. 2006). Namely, during voiding only the dome shows strong contraction, whereas the shortening of the base is impaired (Hirahara et al. 2006). An interesting question is how the different parts of the urinary bladder can respond differently to the same stimulation.

During electrical stimulation of the parasympathetic nerves, acetylcholine (ACh) and adenosine triphosphate (ATP) are co-released from the nerve terminals. ACh and ATP stimulate muscarinic and purinergic receptors of the smooth muscle, respectively, and elicit bladder contraction (Dowdall et al. 1974; Kasakov and Burnstock 1982; Theobald and de Groat 1989). Although ATP plays an additional role 
in evoking the contraction of the detrusor in many species (rabbit, rat, mice; Calvert et al. 2001; Aronsson et al. 2010; Gomez-Pinilla et al. 2011), it has little, if any, role in healthy human bladders (Sjogren et al. 1982; Bayliss et al. 1999). On the other hand, the proportion of atropine-resistant, nerve-mediated contractions in human bladders increases in several pathological conditions (interstitial cystitis, idiopathic detrusor overactivity, etc.; Bayliss et al. 1999; Sjogren et al. 1982; O'Reilly et al. 2002). A possible explanation of the different phenotypes of contractions is that in bladders from pathological states, ectonucleotidase enzyme activity is reduced. Consequently, some of the released ATP is able to activate the detrusor and generate the atropine-resistant component of the contractions (Harvey et al. 2002).

It is known that co-activation of nicotinic and $\mathrm{P} 2 \mathrm{X}_{2} \mathrm{pu}-$ rinergic receptors inhibits the functions of both ion channels through direct protein-protein interaction on the neuronal cell membrane (Nakazawa 1994; Barajas-Lopez et al. 1998; Zhou and Galligan 1998; Khakh et al. 2000, 2005). Similar interaction between nicotinic and purinergic receptors in rat urinary bladder smooth muscle has been recently described (Jenes et al. 2012).

In this work, we investigated the cholinergic and purinergic contribution to the $\mathrm{Ca}^{2+}$ homeostasis of smooth muscle cells isolated from human urinary bladders. We present evidence about the location dependence and suggest a possible physiological relevance of purinergic-cholinergic receptor cross-inhibition in a human non-neural tissue.

\section{Materials and Methods}

\section{Human urinary bladder smooth muscle cell culture}

Human bladder strips were prepared from histological specimens excised from patients undergoing bladder surgery due to various conditions (benign prostate hyperplasia, tumor of the prostate or bladder, nephrolith). The use of human detrusor specimens was approved by the Ethical Committee of the University of Debrecen. Informed consent was obtained from all subjects.

We investigated urinary bladder specimens from 12 male patients. The age of the patients was $69 \pm 5$ years (mean \pm $\mathrm{SD})$. Six patients had benign prostatic hyperplasia (BPH), three patients suffered from carcinoma of the urinary bladder, two patients had prostate cancer, and one had undergone surgery for stones in the bladder. Their International prostate symptom score (IPSS) ranged from 3 to 17 , or it was not evaluated in patients who had urethral catheters.

There were two definite sites of the bladder where samples were taken from: one for the dome and one for the base. Anterior wall of bladders were cut open in the midsagittal plane. Dome samples originate from the anterior wall of the dome, just from the wall next to the midsagittal incision. Base samples originate from the trigonum vesicae. The surgical procedure determined whether samples were collected from the dome only, from the base only, or from both the dome and the base.

Smooth muscle cells were cultured as described previously (Jenes et al. 2012), with an increased collagenase concentration to $1 \mathrm{mg} / \mathrm{ml}$. Following removal of the mucosal layer the muscle piece was placed into trypsin $(0.75 \mathrm{mg} / \mathrm{ml})$ - EDTA $(0.4 \mathrm{mg} / \mathrm{ml})$ solution for 30 minutes at $37^{\circ} \mathrm{C}$. After mechanical shredding, pieces were digested in RPMI 1640 solution containing $1 \mathrm{mg} / \mathrm{ml}$ collagenase $\left(45\right.$ minutes at $\left.37^{\circ} \mathrm{C}\right)$. Cells were washed in RPMI solution containing $10 \%$ FBS, then seeded onto glass coverslips. Experiments were carried out on 5-7-day-old cultures.

\section{Fluorescent measurement of $\left[\mathrm{Ca}^{2+}\right]_{i}$}

Changes in the concentration of $\left[\mathrm{Ca}^{2+}\right]_{i}$ were detected using the fluorescent dye Fura-2 as described in our previous reports (Bíró et al. 1998; Csernoch et al. 2000; Jenes et al. 2012). The coverslips with the Fura-2 loaded cells $\left(90 \mathrm{~min}, 37^{\circ} \mathrm{C}, 15 \mu \mathrm{M}\right.$ Fura-2 AM) were placed on the stage of an inverted fluorescence microscope (Diaphot, Nikon, Japan). The measuring bath was constantly perfused with HEPES-buffered Tyrode's solution (in mM: $137 \mathrm{NaCl}, 5.4 \mathrm{KCl}, 0.5 \mathrm{MgCl}_{2}, 1.8 \mathrm{CaCl}_{2}, 11.8$ HEPES-NaOH), supplemented with $1 \mathrm{~g} / \mathrm{l}$ glucose ( $\mathrm{pH}$ 7.4).

Following test solutions - dissolved in HEPES-buffered Tyrode's solution - were directly applied to the vicinity of the cells through a local perfusion capillary: ATP $(180 \mu \mathrm{M})$, nicotine $(5 \mu \mathrm{M})$ and carbachol $(10 \mu \mathrm{M})$. Experiments were performed at room temperature $\left(22-24^{\circ} \mathrm{C}\right)$. Excitation wavelength was altered between 340 and $380 \mathrm{~nm}$, while the emission was monitored at $510 \mathrm{~nm}$. Background fluorescence was measured at cell-free regions of the coverslip and subtracted automatically. $\left[\mathrm{Ca}^{2+}\right]_{\mathrm{i}}$ levels were calculated according to the method of Grynkiewicz et al. (1985) from the ratio $(R=$ $\left.F_{340} / F_{380}\right)$ of the fluorescence intensities measured with excitation wavelengths $340 \mathrm{~nm}\left(F_{340}\right)$ and $380 \mathrm{~nm}\left(F_{380}\right)$ as previously described (Bíró et al. 1998; Csernoch et al. 2000) using in vivo calibration data.

Time derivative of $\left[\mathrm{Ca}^{2+}\right]$ was calculated and its maximum was taken as the maximum rate of rise. To determine the decay time constant, single exponential function was fitted - using the least squares method - to the declining phase of the calcium transient.

\section{Immunocytochemistry}

Cultured smooth muscle cells were fixed in acetone for 5 min and permeabilized by $0.1 \%$ Triton X-100 (SigmaAldrich) in phosphate buffered saline (PBS, $\mathrm{pH} 7.4$ ), for 10 min. After washing in PBS solution and blocking in 1\% 
bovine serum albumin (BSA, Sigma-Aldrich) for $30 \mathrm{~min}$, cells were incubated with the primary antibodies: anti-P2X (1:100), anti-nAChRa 3 (1:200) and anti-nAChRa 7 (1:200; Santa Cruz Biotechnology, Santa Cruz, CA, USA) overnight. Slides were washed three times in PBS and incubated with fluoresceine isothiocyanate- (FITC) conjugated secondary antibodies (Vector Laboratories, Burlingame, CA, USA) for $45 \mathrm{~min}$ (1:200). The nuclei of the cells were visualised using 4,6-diamidino-2-phenylindole (DAPI, Vector). Cells were examined on a confocal microscope (LSM 510 META, Zeiss, Oberkochen, Germany).

\section{Immunohistochemistry}

Tissue specimens were immediately fixed in $4 \%$ buffered formaldehyde $(24 \mathrm{~h}$ ), embedded in paraffin wax, and $4 \mu \mathrm{m}$ thick sections were cut. Endogenous peroxidase activity was blocked with $3 \% \mathrm{H}_{2} \mathrm{O}_{2}$ in methanol (10 min, room temperature). Non-specific binding was prevented by incubating the sections with bovine serum albumin (BSA) or horse serum (HS, Sigma-Aldrich). Tissue sections were incubated overnight at $4^{\circ} \mathrm{C}$ with anti-P2 $\mathrm{X}_{2}$, anti-nAChRa $\alpha_{3}$, or anti$n A C h R a_{7}$ primary antibodies (1:200). After incubation, the sections were rinsed three times with $\mathrm{PBS}$. When the primary antibody raised in rabbit was used, the tissue sections were incubated with the EnVision system (Dako, Carpinteria, CA, USA), and visualization was achieved by employing the 3,3'-diaminobenzidine (DAB) SK4100 kit (Vector). When primary antibodies raised in goat were used (anti-P2 $\mathrm{X}_{2}$ and anti-nAChRa $a_{7}$, the sections were incubated in biotinylated anti-goat secondary antibodies for $30 \mathrm{~min}$ (1:100, Dako), rinsed with $\mathrm{PBS}$ and incubated with horseradish peroxidaseconjugated streptavidin (30 min; 1:500; room temperature). Visualisation of the immunolabelling was achieved using DAB. The sections were slightly counterstained with haematoxylin. Control experiments (sections incubated overnight without the primary antibodies) were regularly performed.

\section{Statistics}

Data obtained from any cell were normalized to the first ATP-evoked response of the same cell. The groups were
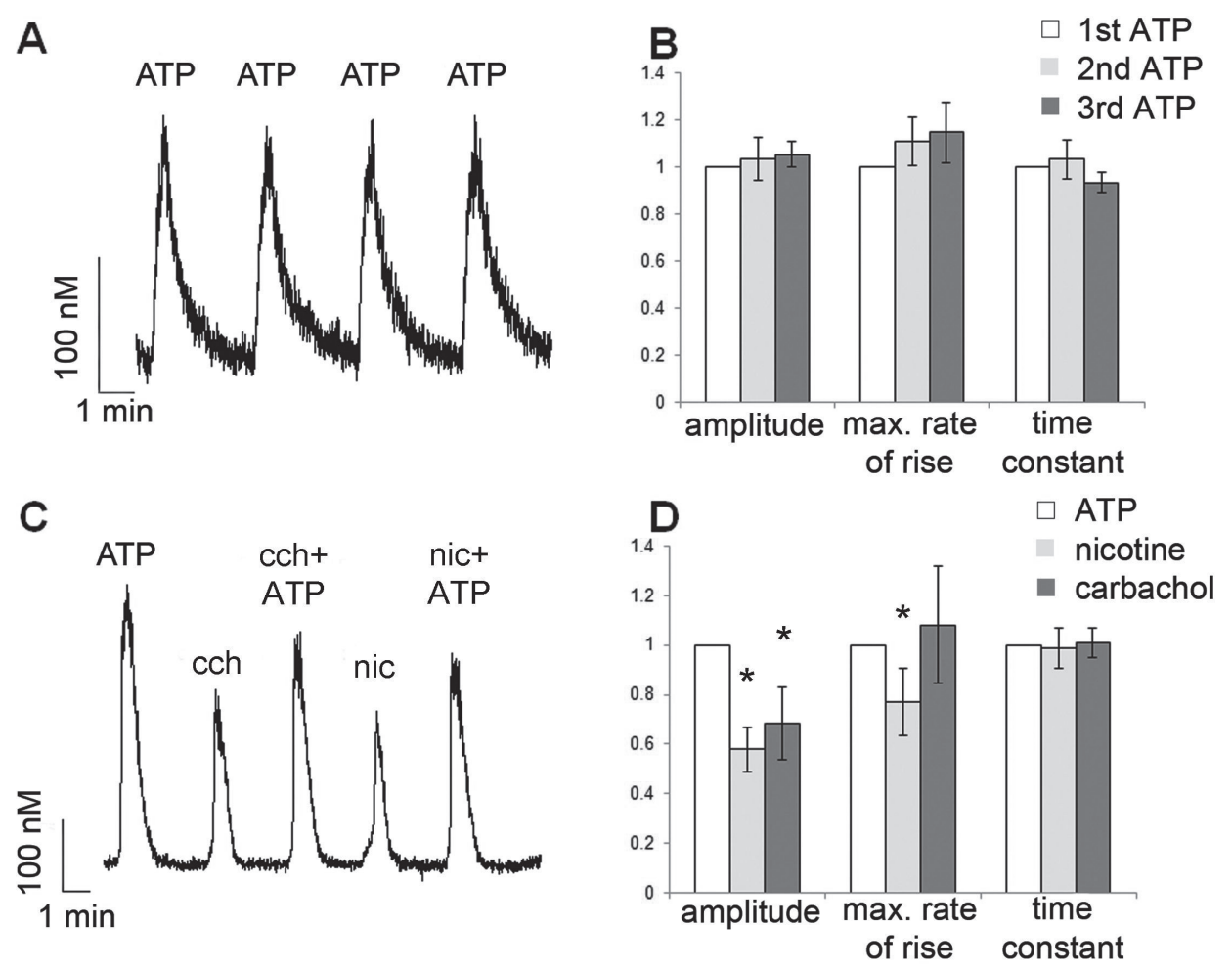

Figure 1. Calcium transients evoked by repetitive ATP applications or by cholinergic agonists on cultured smooth muscle cells of human urinary bladders. A. ATP-evoked $(180 \mu \mathrm{M}) \mathrm{Ca}^{2+}$ transients in urinary bladder smooth muscle cells. B. Pooled data from 10 similar experiments where the main parameters (amplitude, maximal rate of rise, decay time constant) of the $2^{\text {nd }}$ and $3^{\text {rd }}$ ATP-evoked transients were normalized to those of the first response. C. Representative $\mathrm{Ca}^{2+}$ transients induced by carbachol (cch, $\left.10 \mu \mathrm{M}\right)$, nicotine (nic, $\left.5 \mu \mathrm{M}\right)$, and/or ATP $(180 \mu \mathrm{M})$. D. Normalized parameters characterizing the $\mathrm{Ca}^{2+}$ transients produced by the application of ATP, nicotine, or carbachol. ${ }^{\star}$ indicates significant difference from the corresponding ATP-evoked parameter $(p<0.05)$. 
compared by Student's $t$-tests. Differences were regarded significant at $p<0.05$. Data are expressed as mean \pm SEM.

\section{Results}

Effect of the repetitive ATP application on the $\mathrm{Ca}^{2+}$ transients of cultured smooth muscle cells from human urinary bladders

To study the effects of the purinergic and cholinergic stimulation, cultured human urinary bladder smooth muscle cells were used. Throughout the experiments, all cells responded to ATP. First, the shape and reproducibility of the ATP-induced $\mathrm{Ca}^{2+}$ transients were determined. ATP was applied for 40 seconds several times (with 3 minute intervals) to induce $\mathrm{Ca}^{2+}$ transients by the activation of $\mathrm{P} 2$ receptors. There were no significant changes in any of the investigated parameters (amplitude, maximal rate of rise, decay time constant) of the consecutive $\mathrm{Ca}^{2+}$ transients (Fig. 1A,B). In addition, no difference was observed between smooth muscle cells isolated from the base or the dome of the bladders.

\section{Effects of nicotine and carbachol application on the $\mathrm{Ca}^{2+}$} transients

Nicotine and carbachol ( $5 \mu \mathrm{M}$ and $10 \mu \mathrm{M}$, respectively) induced $\mathrm{Ca}^{2+}$ transients in 30 cells from 54 cells investigated (56\%) and 19 cells from 42 cells investigated (44\%), respectively. The amplitude and the maximal rate of rise of the calcium transients evoked by either agonist were significantly lower than those of the responses evoked by ATP, but the decay time constants were the same (Fig. 1C,D). The effects of nicotine and carbachol were not significantly different from one another (Fig. 1D).

Cholinergic agonists (nicotine and/or carbachol) produced calcium transients in a lower proportion of cells from the base (in 22 cells from 42 cells tested, 52\%) than from the dome (in 14 cells from 17 cells tested, 82\%). The amplitudes of the responses, however, did not differ at all (58 $\pm 7 \%$ and $54 \pm 8 \%$ of the ATP-evoked responses in the base and in the dome, respectively).

Interaction between purinergic and cholinergic pathways at the level of $\mathrm{Ca}^{2+}$ transients of cultured smooth muscle cells isolated from the base of human urinary bladders

The additive effect of ATP and the cholinergic agonist (nicotine or carbachol) was smaller than the sum of their effect individually (even smaller than the effect of ATP alone). In the base (Fig. 2A) the inhibition exhibited by nicotine was significantly more pronounced than in the dome (Fig. 2B) of the bladders.

In the base, nicotine massively reduced the amplitude of the ATP-evoked $\mathrm{Ca}^{2+}$ transients (to $42 \pm 6 \%$, in 54 cells, prepared from 9 patients), whereas the amplitude of the $\mathrm{Ca}^{2+}$ transients evoked by ATP and carbachol were $56 \pm 9 \%$ of the ATP-evoked responses (in 29 cells, prepared from 6 patients), (Fig. 3). The responses to the combined application of ATP and the cholinergic agonist were $47 \pm 5 \%$ of the ATP-evoked responses (Fig. 3). In 22 cells where the effects
A

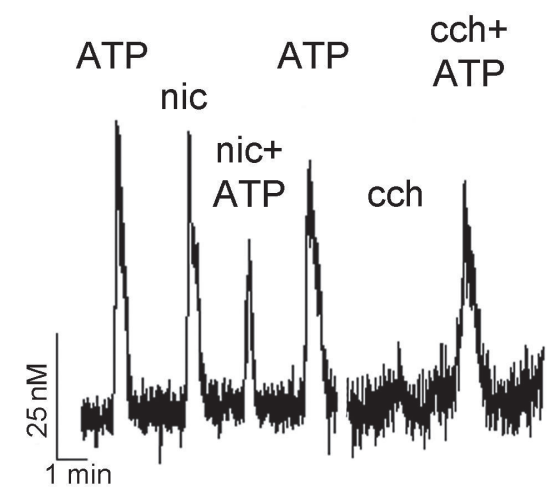

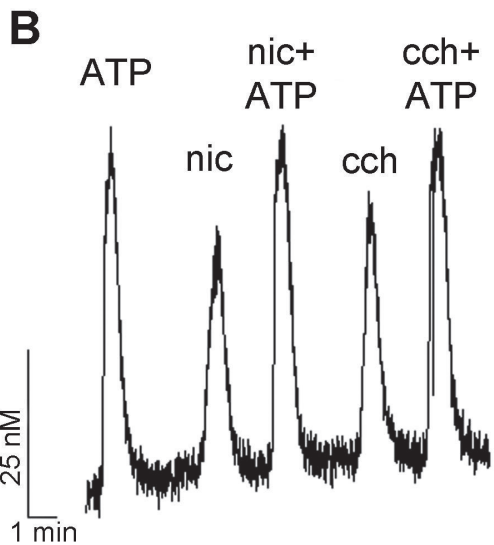

Figure 2. Representative calcium transients evoked by cholinergic and purinergic agonists on cultured smooth muscle cells from the base and from the dome of human urinary bladders. A. Representative $\mathrm{Ca}^{2+}$ transients induced by purinergic, cholinergic, or combined purinergic-cholinergic stimulation of a smooth muscle cell isolated from the base of a urinary bladder. B. Representative $\mathrm{Ca}^{2+}$ transients induced by purinergic, cholinergic, or combined purinergic-cholinergic stimulation of a smooth muscle cell isolated from the dome of a urinary bladder. The concentrations applied were $180 \mu \mathrm{M}, 10 \mu \mathrm{M}, 5 \mu \mathrm{M}$ for ATP, carbachol (cch) and nicotine (nic), respectively. 


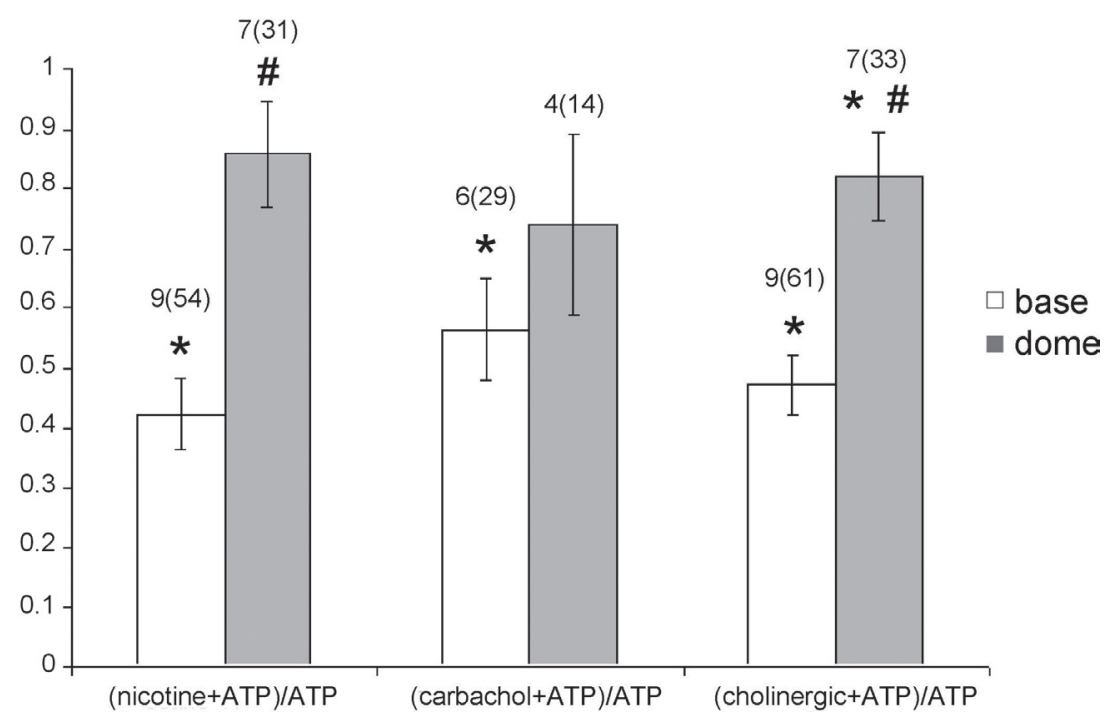

Figure 3. Amplitudes of the $\mathrm{Ca}^{2+}$ transients evoked by cholinergic and purinergic agonists on cultured smooth muscle cells. The amplitudes of the transients evoked by ATP in the presence of $5 \mu \mathrm{M}$ nicotine or $10 \mu \mathrm{M}$ carbachol were normalized to the amplitudes of the transients evoked by ATP alone. Each bar summarizes the effect of drug applications indicated underneath the X axis. The first number above each column indicates the number of patients, whereas the second number (in parentheses) gives the number of cells/drug applications investigated. ${ }^{*}$ indicates if the combined effect was significantly different from that of the ATP alone $(p<0.05) . ;$ indicates significant difference between the responses of the base and of the dome $(p<0.05)$.

of both nicotine and carbachol were tested, the former was usually more effective in reducing the amplitudes of the ATP-related transients.

In two patients, who had the mildest symptoms, and we obtained sample from the base (one patient with carcinoma transitiocellulare urinae, IPSS 6, and one patient with benign prostatic hyperplasia, IPSS 9), we found the cholinergic-purinergic interaction to be much less pronounced. In these cases, nicotine and carbachol, applied together with ATP, induced transients nearly the same amplitude $(86 \pm 11 \%$ and $80 \pm 16 \%$, respectively) as ATP alone did.

Effects of ATP, nicotine, and carbachol on the $\mathrm{Ca}^{2+}$ transients of cultured smooth muscle cells from the dome of human urinary bladders

The cross-reactivity between the purinergic and cholinergic receptors was also studied in smooth muscle cells $(n=33)$ from the dome of urinary bladders cultured from 7 patients (Fig. 2B). Apparently, there was significantly less prominent cross-reactivity between the purinergic and cholinergic pathways in the cells from the dome of the bladders. When the ATP was administered together with either nicotine or carbachol, it induced similar $\mathrm{Ca}^{2+}$ transients than ATP did alone (Fig. 2B).

On smooth muscle cells cultured from the dome of urinary bladders, neither nicotine ( $86 \pm 9 \%, n=31)$ nor carbachol ( $74 \pm 15 \%, n=14$, from 4 patients) exerted sig- nificant inhibition on the amplitudes of ATP-evoked $\mathrm{Ca}^{2+}$ transients (Fig. 3), although, a slight overall inhibition by the cholinergic agents was observed $(82 \pm 8 \%)$.

Expression of nicotinic and $\mathrm{P} 2 \mathrm{X}_{2}$ receptors in smooth muscle cell cultures and urinary bladder tissue sections

To determine the subtype-specific expression and distribution of the nicotinic receptors, cultured smooth muscle cells from human urinary bladders and bladder tissue sections were used. Cultured smooth muscle cells from the bladders showed $\alpha_{3}$ and $\alpha_{7}$ nicotinic acetylcholine receptor immunopositivity. The results of the immunohistochemistry experiments performed on tissue sections also confirmed the presence of both $\alpha_{3}$ and $\alpha_{7}$ nicotinic receptor subunits (Fig. 4).

The presence of $\mathrm{P} 2 \mathrm{X}_{2}$ receptors was also demonstrated using both cultured cells and tissue sections. Both nicotinic receptor subunits $\left(\alpha_{3}\right.$ and $\left.\alpha_{7}\right)$ and the $\mathrm{P} 2 \mathrm{X}_{2}$ receptors showed similar distribution on the dome and on the base of all urinary bladder samples (Fig. 4).

\section{Discussion}

This report presents evidence about the localization-dependence and suggests a possible physiological relevance of the cross-talk between purinergic and cholinergic receptors in 


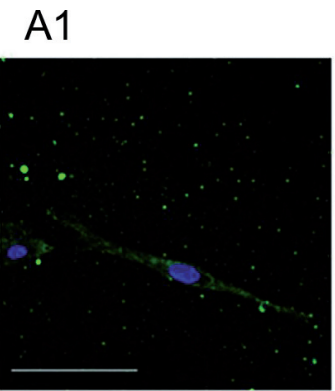

B1

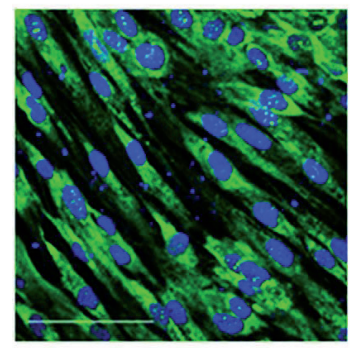

C1

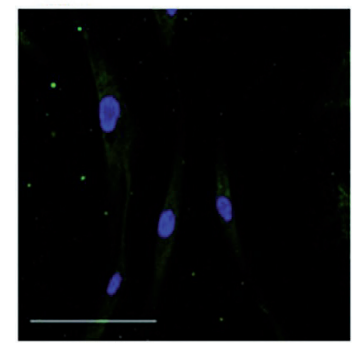

A2

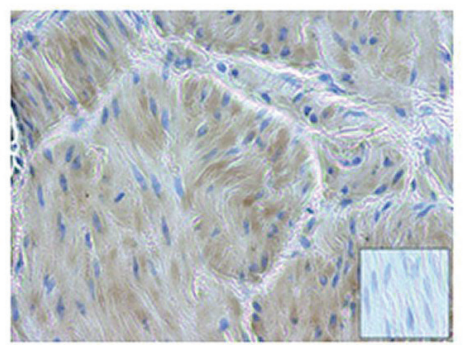

B2

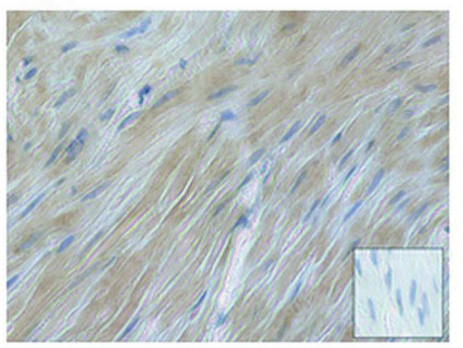

C2

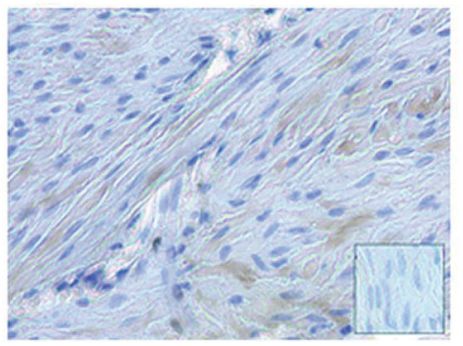

A3

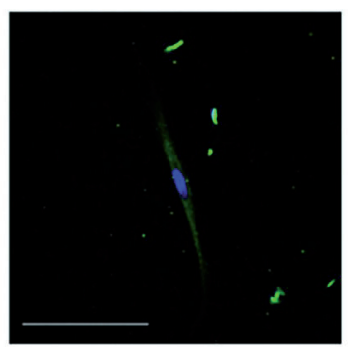

B3

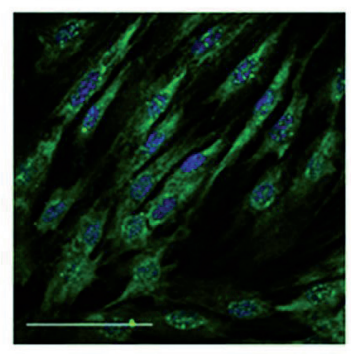

C3

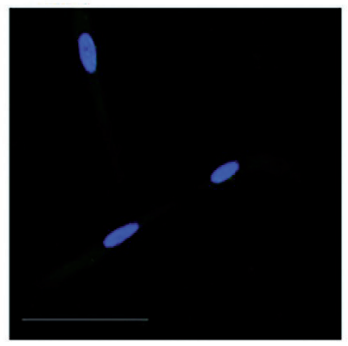

A4

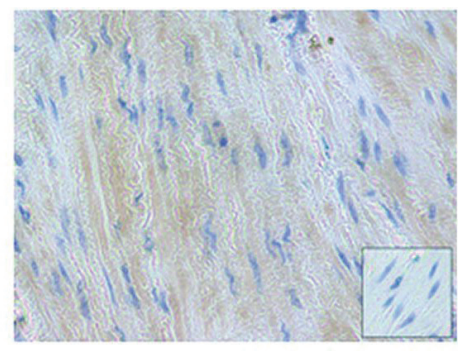

B4

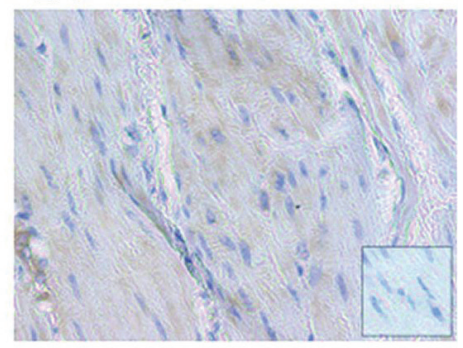

C4

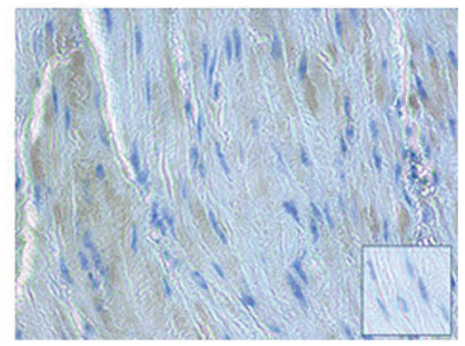

Figure 4. $\mathrm{P} 2 \mathrm{X}_{2}$, nicotinic $\alpha_{7}$, and $\alpha_{3}$ receptor-specific immunoreactivity of cultured human urinary bladder smooth muscle cells and histological tissue sections. A1-A4: Demonstration of the expression of $\mathrm{nAChRa}$ receptor subunits. A1: cultured smooth muscle cells isolated from the dome; A2: histological tissue section prepared from the dome; A3: cultured smooth muscle cells isolated from the base; A4: histological tissue section prepared from the base. B1-B4: Expression of $\mathrm{nAChRa}$ receptor subunits. The organization of the images is the same as in A1-A4. C1-C4: Expression of $\mathrm{P} 2 \mathrm{X}_{2}$ receptors. The organization of the images is the same as in A1-A4. On the immunocytochemistry images green colour represents the $\mathrm{nAChRa}_{7}(\mathrm{~A} 1, \mathrm{~A} 3), \mathrm{nAChRa} 3$ (B1, B3), or P2X $\mathrm{X}_{2}$ receptor-specific (C1, C3) immunoreactivity, DAPI shows the cell nuclei. Calibration bars indicate $25 \mu \mathrm{m}$. The brown colour (DAB) in the immunohistochemistry images marks cells expressing nAChRa7 (A2, A4), nAChRa 3 (B2, B4), or $\mathrm{P} 2 \mathrm{X}_{2}$ receptors (C2, C4). All sections were slightly counterstained with haematoxylin. Original magnification is $\times 200$. Inserts show negative controls.

a non-neural tissue. We suggest that the inhibition between these signaling pathways is one of the underlying reasons of the inadequate contraction reported in the base of the urinary bladders of patients with outlet obstruction during voiding.

We demonstrated that nicotine and carbachol reduced - or even prevented - the ATP-evoked $\mathrm{Ca}^{2+}$ transients in smooth muscle cells from urinary bladders. The cross-inhibition was more prominent in the base of the bladder. Similar cross-interaction was already described in rat smooth muscle cells from the base of the urinary bladder, when the smooth muscle cells were isolated from 8-12 weeks old animals (Jenes et al. 2012).

\section{Cholinergic and purinergic receptor activation of human urinary bladder smooth muscle cells}

Our results suggest interaction between P2X purinergic and a putative cholinergic receptor in detrusor. Previous experiments gave evidence on cholinergic and purinergic interaction between neuronal nicotinic and $\mathrm{P} 2 \mathrm{X}_{2}$ purinergic receptors in sympathetic ganglia (Nakazawa 1994), hippocampal neurons (Khakh et al. 2005), and myenteric neurons (Barajas-Lopez et al. 1998; Zhou and Galligan 1998; Brown and Galligan 2003). In these systems, co-application of a nicotinic and a purinergic agonist produced 
smaller additive response (inward currents, calcium influx) than that was expected from independent receptor stimulations.

In our study both carbachol and nicotine were found to activate the acethylcholine receptors of the urinary bladder smooth muscle cells. The muscarinic receptor blocker atropine did not modify the purinergic-cholinergic interactions (13 cells from 2 patients). When we found cross-inhibition applying ATP and nicotine/carbachol together, atropine could not prevent this interaction, in addition, when such interaction was not observed, atropine did not invoke such interaction either. These data suggest that muscarinic acethylcholine receptors do not have any role in the purinergic-cholinergic receptor cross-inhibition. Among the nicotinic receptor subunits $\alpha_{1}, \alpha_{3}, \alpha_{4}, \alpha_{7}$, and $\alpha_{9}$ can be activated by both nicotine and carbachol (Alexander et al. 2008). However, the affinity of the $\alpha_{1}, \alpha_{7}$, and $\alpha_{9}$ subunits to carbachol is similar to, or even higher than that to nicotine. Since the inhibitory effect of carbachol on the ATP-evoked response was smaller $(46 \pm 10 \%)$ than that of nicotine $(71 \pm 7 \%)$, we imply that the $\alpha_{3}$ nicotinic $\mathrm{ACh}$ receptor subunit is involved in the cross-talk with the purinergic receptors, however, the role of other subtypes can not be excluded.

Furthermore, the functional results clearly indicated that nicotinic receptors are present in the smooth muscle cells of the human bladder. It must be noted that although our immunohistochemistry data suggested the presence of $\alpha_{7}$ nicotinic receptor subunits in human bladders, it is unlikely that this subunit alone is responsible for mediating the effects of cholinergic stimulation, as it was reported in rat urinary bladders (Jenes et al. 2012). The possible roles of other nicotinic receptor subunits are suggested by the marked difference between the cholinergic agonists that are capable of interfering with purinergic stimulation in rats and humans. More specifically, in rats only carbachol inhibits the ATP-evoked transients, whereas nicotine does not. In contrast, in the human bladder nicotine was also effective and it inhibited the ATP-evoked transients at least as effectively as carbachol did. In line with the implication of the significance of other nicotinic receptor subunits, our immunostaining data indicated the presence of $\alpha_{3}$ nicotinic receptor both in cultures and urinary bladder tissue samples. Our study, therefore, provides evidence that nicotinic receptors are functionally present in the bladder smooth muscle. Additionally, we demonstrated that nicotinic receptors may play an important role in modulating the activity of purinergic receptors.

It seems probable that among purinergic receptors, $\mathrm{P} 2 \mathrm{X}_{2}$ receptors have importance in the cholinergic-purinergic interaction in human bladders. The observation that the ATP-evoked $\mathrm{Ca}^{2+}$ transients displayed no desensitization is an important piece of evidence corroborating the hypothesis about the functional relevance of $\mathrm{P} 2 \mathrm{X}_{2}$ receptors, especially as they are known to desensitize slowly and recover rapidly (North 2002). In fact, our immunocytochemistry and immunohistochemistry data also indicated the presence of $\mathrm{P} 2 \mathrm{X}_{2}$ receptors. It has been noted that both $\mathrm{P} 2 \mathrm{X}_{2}$ receptor expression and the consequent purinergic component of detrusor contractions are significantly elevated in patients with idiopathic detrusor instability (O'Reilly et al. 2002). We propose, therefore, that cholinergic modulation of the $\mathrm{P} 2 \mathrm{X}_{2}$ receptors may be behind the impaired bladder function of these patients.

It has to be mentioned, that our patients had lower urinary tract symptoms with different severity, and we have no information about a possible cholinergic-purinergic interaction in healthy human bladders. Nevertheless, this inhibition seems to be more pronounced in our patients with more severe symptoms (higher International Prostate Symptom Score, larger post-void residual volume, usually complete urinary retention). On the other hand, patients with complete urinary retention had urethral catheters, and the possibility that catheters might influence the observed interaction cannot be excluded.

Acknowledgements. This work was supported by grants from the Hungarian Scientific Research Fund (OTKA F68393, K75604), Hungarian Ministry of Health (ETT 186/2009), Hungarian Ministry of Education (TÁMOP-4.2.2-08/2008-0019), the European Union and the European Social Fund (TÁMOP-4.2.2.A-11/1/ KONV-2012-0025).The authors are indebted for the excellent technical assistance from R. Öri and I. Kiss.

\section{References}

Alexander S. P. H., Mathie A., Peters J. A. (2008): Guide to receptors and channels (GRAC). Br. J. Pharmacol. 153, S98-100 http://dx.doi.org/10.1038/sj.bjp.0707746

Aronsson P., Andersson M., Ericsson T., Giglio D. (2010): Assessment and characterization of purinergic contractions and relaxations in the rat urinary bladder. Basic Clin. Pharmacol. Toxicol. 107, 603-613 http://dx.doi.org/10.1111/j.1742-7843.2010.00554.x

Barajas-Lopez C., Espinosa-Luna R., Zhu Y. (1998): Functional interactions between nicotinic and P2X channels in shortterm cultures of guinea-pig submucosal neurons. J. Physiol. 513, 671-683 http://dx.doi.org/10.1111/j.1469-7793.1998.671ba.x

Bayliss M., Wu C., Newgreen D., Fry C. H. (1999): A quantitative study of atropine-resistant contractions in human detrusor smooth muscle, from stable, unstable and obstructed bladders. J. Urol. 162, 1833-1839 http://dx.doi.org/10.1016/S0022-5347(05)68247-X

Bíró T., Szabó I., Kovács L., Hunyadi J., Csernoch L. (1998): Distinct subpopulations in $\mathrm{HaCaT}$ cells as revealed by the characteristics of intracellular calcium release induced by phosphoinositidecoupled agonists. Arch. Dermatol. Res. 290, 270-276 
http://dx.doi.org/10.1007/s004030050303

Brown E. N., Galligan J. J. (2003): Muscarinic receptors couple to modulation of nicotinic ACh receptor desensitization in myenteric neurons. Am. J. Physiol. Gastrointest. Liver Physiol. 285, G37-44

Calvert R. C., Thompson C. S., Khan M. A., Mikhailidis D. P., Morgan R. J., Burnstock G. (2001): Alterations in cholinergic and purinergic signaling in a model of the obstructed bladder. J. Urol. 166, 1530-1533 http://dx.doi.org/10.1016/S0022-5347(05)65825-9

Csernoch L., Hunyadi J., Kovács L. (2000): Calcium release activated calcium entry in a human skin derived cell line. Exp. Dermatol. 9, 200-205 http://dx.doi.org/10.1034/j.1600-0625.2000.009003200.x

Dowdall M. J., Boyne A. F., Whittaker V. P. (1974): Adenosine triphosphate. A constituent of cholinergic synaptic vesicles. J. Biochem. 140, 1-12

Gomez-Pinilla P. J., Pozo M. J., Camello P. J. (2011): Aging differentially modifies agonist-evoked mouse detrusor contraction and calcium signals. Age (Dordr) 33, 81-88 http://dx.doi.org/10.1007/s11357-010-9163-7

Harvey R. A., Skennerton D. E., Newgreen D., Fry C. H. (2002) The contractile potency of adenosine triphosphate and ectoadenosine triphosphatase activity in guinea pig detrusor and detrusor from patients with a stable, unstable or obstructed bladder. J. Urol. 168, 1235-1239 http://dx.doi.org/10.1016/S0022-5347(05)64632-0

Hirahara N., Ukimura O., Ushijima S., YamadaY., Okihara K., Kawauchi A., Miki T. (2006): Four-dimensional ultrasonography for dynamic bladder shape visualization and analysis during voiding. J. Ultrasound. Med. 25, 307-313

Jenes A., Ruzsnavszky F., Telek A., Szigeti G. P., Csernoch L. (2012): A possible role of the cholinergic and purinergic receptor interaction in the regulation of the rat urinary bladder function. J. Muscle. Res. Cell. Motil. 32, 421-431 http://dx.doi.org/10.1007/s10974-012-9285-x

Kasakov L., Burnstock G. (1982): The use of the slowly degradable analog, alpha, beta-methylene ATP, to produce desensitisation of the P2-purinoceptor: effect on non-adrenergic, noncholinergic responses of the guinea-pig urinary bladder. Eur J. Pharmacol. 86, 291-294 http://dx.doi.org/10.1016/0014-2999(82)90330-2

Khakh B. S., Zhou X., Sydes J., Galligan J. J., Lester H. A. (2000): State-dependent cross-inhibition between transmitter-gated cation channels. Nature 406, 405-410 http://dx.doi.org/10.1038/35019066
Khakh B. S., Fisher J. A., Nashmi R., Bowser D. N., Lester H. A. (2005): An angstrom scale interaction between plasma membrane ATP-gated P2X2 and $\alpha 4 \beta 2$ nicotinic channels measured with fluorescence resonance energy transfer and total internal reflection fluorescence microscopy. J. Neurosci. 25, 6911-6920 http://dx.doi.org/10.1523/JNEUROSCI.0561-05.2005

Malone-Lee J., Wahedna I. (1993): Characterisation of detrusor contractile function in relation to old age. Br. J. Urol. 72, 873-880 http://dx.doi.org/10.1111/j.1464-410X.1993.tb16289.x

Nakazawa K. (1994): ATP-activated current and its interaction with acetylcholine-activated current in rat sympathetic neurons. J. Neurosci. 14, 740-750

North R. A. (2002): Molecular physiology of P2X receptors. Physiol. Rev. 82, 1013-1067

O'Reilly B. A., Kosaka A. H., Knight G. F., Chang T. K., Ford A. P., Rymer J. M., Popert R., Burnstock G., McMahon S. B. (2002): $\mathrm{P} 2 \mathrm{X}$ receptors and their role in female idiopathic detrusor instability. J. Urol. 167, 157-164 http://dx.doi.org/10.1016/S0022-5347(05)65403-1

Resnick N. M., Yalla S. V. (1987): Detrusor hyperactivity with impaired contractile function. An unrecognized but common cause of incontinence in elderly patients. JAMA 257, 3076-3081 http://dx.doi.org/10.1001/jama.1987.03390220074024

Sjogren C., Andersson K. E., Husted S., Mattiasson A., Moller-Madsen B. (1982): Atropine resistance of transmurally stimulated isolated human bladder muscle. J. Urol. 128, 1368-1371

Theobald R. J., de Groat W. D. (1989): The effects of purine nucleotides on transmission in vesical parasympathetic ganglia of the cat. J. Auton. Pharmacol. 9, 167-181 http://dx.doi.org/10.1111/j.1474-8673.1989.tb00208.x

Yoshida M., Homma Y., Inadome A., Yono M., Seshita H., Miyamoto Y., Murakami S., Kawabe K., Ueda S. (2001): Age-related changes in cholinergic and purinergic neurotransmission in human isolated bladder smooth muscles. Exp. Gerontol. 36, 99-109 http://dx.doi.org/10.1016/S0531-5565(00)00175-3

Zhou Z., Galligan J. J. (1998): Non-additive interaction between nicotinic cholinergic and $\mathrm{P} 2 \mathrm{X}$ purinergic receptors in guineapig enteric neurons in culture. J. Physiol. 513, 685-697 http://dx.doi.org/10.1111/j.1469-7793.1998.685ba.x

Received: October 29, 2012

Final version accepted: January 25, 2013 